\title{
Utilization of Pyrolytic Carbon Black Waste for the Development of Sustainable Materials
}

\author{
Faizan Ali ${ }^{1}$, Mishmal Ahmed Khan ${ }^{1}$, Muhammad Ahmed Qurashi ${ }^{1}$, \\ Syyed Adnan Raheel Shah ${ }^{1, *}$, Nasir Mahmood Khan ${ }^{2}$, Zia Khursheed ${ }^{1}$, Hafiz Shahzaib Rahim ${ }^{1}$, \\ Hunain Arshad ${ }^{1}$, Muhammad Farhan ${ }^{1}$ and Muhammad Waseem ${ }^{3}$ \\ 1 Department of Civil Engineering, Pakistan Institute of Engineering \& Technology, Multan 60000, Pakistan; \\ bababukhari1980@gmail.com (F.A.); 2kx8civil33@piet.edu.pk (M.A.K.); 2kx5civil114@piet.edu.pk (M.A.Q.); \\ 2kx8civil31@piet.edu.pk (Z.K.); 2kx8civil34@piet.edu.pk (H.S.R.); hunainarshad@piet.edu.pk (H.A.); \\ muhammadfarhan@piet.edu.pk (M.F.) \\ 2 Pakistan Engineering Council, Ataturk Avenue (East), G-5/2, Islamabad 44000, Pakistan; kmnasir@pec.org.pk \\ 3 Bayreuth Centre for Ecology and Environmental Research, University of Bayreuth, 95440 Bayreuth, \\ Germany; muhammad.waseem@uni-bayreuth.de \\ * Correspondence: syyed.adnanraheelshah@uhasselt.be; Tel.: +92-300-791-4248
}

Received: 29 December 2019; Accepted: 1 February 2020; Published: 4 February 2020

\begin{abstract}
The sustainable development of materials is one of the key targets in the modern era of engineering. These materials are developed by different waste products, following the concept of the circular economy. This study focuses on investigating the properties of concrete using carbon black as a partial replacement of natural fine aggregate at different percentages. Experiments were designed according to the British Standard (BS1881-Part-119) and American Standard (ASTM C-78) by including carbon black in concrete beams to perform as filler material to develop sustainable concrete. In this study, mechanical properties of concrete were targeted by developing beams using different percentages $(0 \%, 25 \%, 50 \%, 75 \%$, and $100 \%)$ as a replacement of fine aggregates. These beams were tested for flexural strength and, later on, the same beams were cut in the form of cubes, following the equivalent cube test mechanism for the compressive strength test. The waste carbon black lightweight concrete developed in this study was utilized for both structural and non-structural purposes. At 25\% and $50 \%$ replacement, the strength of lightweight concrete varied from 20-18 $\mathrm{MPa}$, and according to American Concrete Institute (ACI) standards, lightweight concrete at 28 days strength with $\geq 17 \mathrm{MPa}$ can be used as structural concrete, and the remaining $75 \%$ and $100 \%$ replacement concrete can be used for non-structural purposes. This study will help in the development of economical eco-friendly sustainable concrete materials.
\end{abstract}

Keywords: sustainable; eco-friendly; materials; waste management

\section{Introduction}

Globally, for development purposes, the material that is utilized the most is concrete [1]. Due to the rapid utilization of concrete, the manufacturing of cement is also expanding every day, which contributes to environmental pollution due to the release of $\mathrm{CO}_{2}$ [2,3]. Moreover, the demand for concrete manufacturing ingredients, i.e., cement, sand, and aggregate, is also varying concurrently [4]. On a regular basis, conventional concrete is used for infrastructure development [5]. However, the density of that type of concrete is very high, which contributes to the high self-load for structure [6,7]. To resist this loading effect, extra measures (i.e., reinforcing) are required to be taken [8]. Because of all these aspects, the consumption of lightweight concrete is expanding day by day $[9,10]$. Lightweight concrete is very helpful in minimizing this effect and makes a construction durable and strong due to 
less density, better strength, and thermal insulation [11-13]. The development of lightweight concrete as a structural material has been under way ever since the Roman Empire. Likewise, their sensible utilization occurred when lightweight concrete ships were developed by the American Emergency Fleet Corporation [14]. Furthermore, a series of investigative reviews has been conducted by numerous scholars on the evolution of lightweight concrete by employing a variety of substances, such as ceramist and pottery [15], leca, argex and arlita [16], limestone [14], eps beads [17], rice husk ash [18], vermiculite [9], automotive shredder residues [19], waste polystyrene [20], polyolefins waste [21], polyurethane foam [22], etc. Moreover, approximately 1.5 billion tires are traded every year worldwide and about $50 \%$ is disposed of due to the lack of productive use [23,24]. Each year about 2.5 million tons of tires are disposed of in North America, with 4 billion scrap rubber tires already found in landfills [25]. According to Thomas et al., the disposal amount will increase to 1.2 billion annually at the end of 2030 [24]. To address this problem, waste rubber is added into the concrete as a replacement of fine aggregate. A lot of investigational studies have been conducted to utilize the recycled tire by cutting them into fine units (i.e., crumb rubber) in concrete and pavement [4,26-28]. Earlier research indicates that the physical and durable characteristics of concrete have been enhanced due to the accumulation of crumb rubber [29-31]. Nevertheless, the analysis suggests that the mechanical characteristics of crumb rubber concrete are reduced [32,33]. The primary factor of this decrease is the weak adhesion tie among rubber and cement particles as the rubber surface is very smooth [28,34]. Meanwhile, a lot of investigative approaches show an enrichment of durability and elastic performances and a lack of compressive behavior [35]. At the same time, microcracks are improved due to the enhancement of strain capacity [36]. Another material that contributes to environmental pollution and affects the soil and water characteristics, as well, is carbon black, which originally emerged due to the large-scale utilization of rubber tires [37-39]. The fundamental unstructured material that is obtained from rubber tires is carbon black that is utilized as filler material in rubber and plastic products. It is a very popular material in the rubber industry because it enhances the resistance and mechanical properties of rubber. Usually, it is identified as a pyrolytic carbon black due to its higher \% friction in tires and carbonaceous materials [37,40], since around $74-76 \%$ of tires are manufactured with carbon built substantial [41]. Earlier experimental studies on the recycling and utilization of carbon black have been done by numerous researchers [25,41-43]. Previous research also elaborates that carbon black is helpful to minimize the crack appearance in concrete prisms when they are subjected to bending, and it also enhances their conductivity and mechanical assets [42,44]. Similarly, another research examines the performance of concrete by substituting various fractions of cement and sand with carbon black $[3,45]$. Furthermore, efficient results have been obtained by a substitution of nanocarbon black into concrete as an additive. The effect of nanocarbon black is amended by the conductivity and mechanical characteristics of concrete [46]. Meanwhile, various researchers used carbon black for various experimental purposes, such as the manufacturing of Na-ion batteries [47], to check the impact of carbon black concrete on the corrosion of steel [48], for the advancement of elastic electronic devices [49], by using it as an alternate microfiller [50], for laser displays [51] and sensors [52], to develop concrete that can resist radiations (i.e., shielding concrete) [53], to be utilized as an additive [54], for the use as mechanical reinforcement additive [55,56], etc.

The primary aim of this research is to produce a versatile lightweight concrete by utilizing the material that contributes to environmental pollution (i.e., carbon black). Furthermore, the behavior of specimens is reviewed by applying two sorts of tests, namely destructive and non-destructive testing. With the help of destructive testing, compression and flexural strength are analyzed, and ultrasonic pulse velocity tests are used for non-destructive analysis purposes. An innovative procedure is developed for the compression testing of a standard specimen. The results are analyzed through experimental, analytical, and statistical methods. A relationship is developed between numerous parameters to investigate the performance of carbon black-based concrete. 


\section{Materials and Methods}

\subsection{Materials}

\subsubsection{Basic Material Characteristics}

The basic cementitious material used in this research is according to ASTM [57] with Grade 53 of Type- 1 cement manufactured by Maple Leaf Pvt. Ltd. The physical and chemical properties of cement are shown in Tables 1 and 2 [58-62].

Table 1. Chemical properties of ordinary Portland cement.

\begin{tabular}{ccccccccc}
\hline $\mathrm{LOI}$ & $\mathrm{SiO}_{2}$ & $\mathrm{Al}_{2} \mathbf{O}_{3}$ & $\mathrm{Fe}_{2} \mathbf{O}_{3}$ & $\mathrm{CaO}$ & $\mathbf{M g O}$ & $\mathrm{SO}_{3}$ & $\mathbf{K}_{\mathbf{2}} \mathbf{O}$ & $\mathrm{Na}_{2} \mathbf{O}$ \\
\hline 3.48 & 20.80 & 4.97 & 3.15 & 63.17 & 1.86 & 2.64 & 0.66 & 0.42 \\
\hline
\end{tabular}

Table 2. Basic physical properties of the materials.

\begin{tabular}{cccc}
\hline Property & Unit & Result & Standard \\
\hline \multicolumn{4}{c}{ Ordinary Portland Cement } \\
\hline Bulk Density & $\mathrm{kg} / \mathrm{m}^{3}$ & 1440.00 & ASTM C-188 \\
Normal Consistency & $\%$ & 28.00 & ASTM C-187 \\
Fineness & $\%$ & 96.34 & ASTM C-184 \\
Initial Setting Time & mints & 135.00 & ASTM C-191 \\
Final Setting Time & mints & 190.00 & ASTM C-191 \\
Soundness & mm & 1.00 & BS 196-3 \\
\multicolumn{4}{c}{ Fine Aggregates } \\
\hline Fineness Modulus & - & \\
Bulk Density & $\mathrm{kg} / \mathrm{m}^{3}$ & 1529.00 & ASTM C-29 \\
\hline & Coarse Aggregates & \\
\hline Bulk Density & $\mathrm{kg} / \mathrm{m}^{3}$ & 1500.00 & ASTM C-29 \\
Aggregate Impact Value & $\%$ & 20.45 & BS 812-3 \\
Aggregate Crushing Value & $\%$ & 26.50 & BS 812-3 \\
Los Angeles abrasion & $\%$ & 31.00 & ASTM C-131 \\
Water Absorption & $\%$ & 3.50 & ASTM C-127 \\
\hline
\end{tabular}

The fine aggregate utilized in this research is "Chenab River (sand)" and the maximum size of fine aggregate is $4.75 \mathrm{~mm}$. A coarse aggregate used in this research-“Sakhi Sarwar aggregates"—is composed of mixed limestone (55\%) and sandstone (45\%). It is well-graded and the maximum size is 20 $\mathrm{mm}$. The physical and gradation curve of these aggregates are shown in Table 2 and Figure 1 [63-69].

\subsubsection{Carbon Black}

Carbon black is an extremely fine, one-dimensionally conductive, and spherical shape material that has a higher surface to volume ratio due to its size. It contains a very small quantity of oxygen while the extent of carbon in carbon black is $>98 \%$ [41]. Moreover, it can be produced underneath the control environment due to the deficient ignition or thermal decomposition of gaseous or fluid hydrocarbons $[3,41]$. The material is usually obtained from waste tires through the help of the pyrolysis technique [46]. The gradation curve at various replacement percentages of sand with carbon black and the physical properties of carbon black is shown in Table 3 and Figure $1[63,65]$. As the replacement of sand increased, the fineness of fine aggregates decreased, and the gradation curve became gap graded. In this study, the size of most particles was 0.15 and $0.075 \mathrm{~mm}$. 
Table 3. Basic physical properties of waste carbon black.

\begin{tabular}{cccc}
\hline Property & Unit & Result & Standard \\
\hline Fineness Modulus & - & 0.835 & ASTM C-136 \\
Bulk Density & $\mathrm{kg} / \mathrm{m}^{3}$ & 801 & ASTM C-29 \\
\hline
\end{tabular}

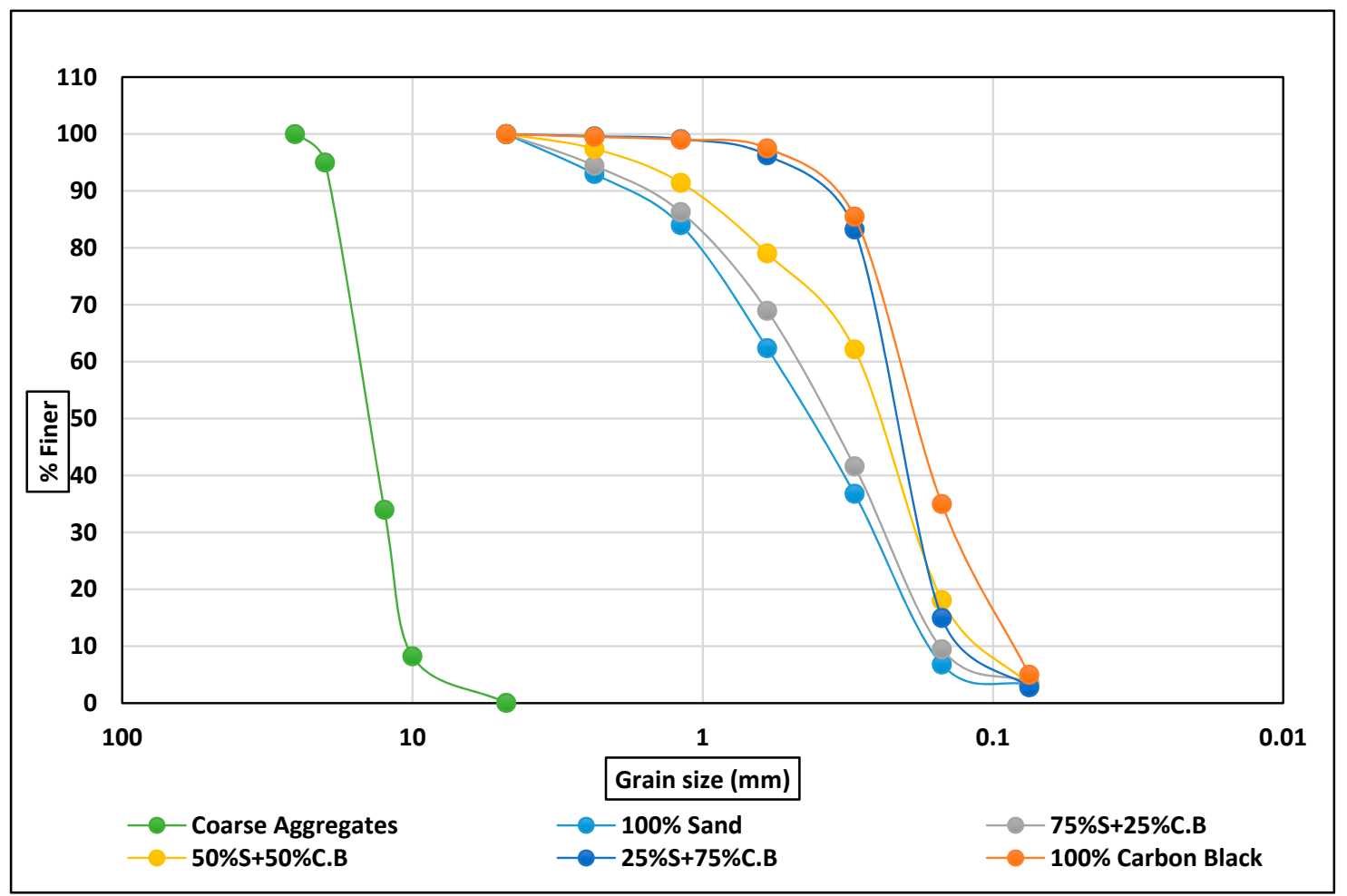

Figure 1. Gradation curve of aggregates.

\subsection{Mix Design and Preparation of Test Specimens}

The utilization of carbon black as a filler material was carried out in this research. Basically, M20 grade was used in this study at a $0.65 \mathrm{w} / \mathrm{c}$ ratio. Fine aggregate was replaced with carbon black by volume at numerous percentages. The mix proportion of waste carbon black lightweight concrete is shown in Table 4.

Table 4. Mix proportion of Waste Carbon Black (WCB) Lightweight Concrete.

\begin{tabular}{lcccccc}
\hline \multicolumn{1}{c}{ Mix ID } & Unit & WCB-0 & WCB-25 & WCB-50 & WCB-75 & WCB-100 \\
\hline W/C Ratio & - & 0.65 & 0.65 & 0.65 & 0.65 & 0.65 \\
Water & Liter & 269.18 & 269.18 & 269.18 & 269.18 & 269.18 \\
Replacement of WCB & $\%$ & 0 & 25 & 50 & 75 & 100 \\
Cement & $\mathrm{kg} / \mathrm{m}^{3}$ & 414.12 & 414.12 & 414.12 & 414.12 & 414.12 \\
Fine Aggregate & $\mathrm{kg} / \mathrm{m}^{3}$ & 660.31 & 494.27 & 330.15 & 164.12 & 0 \\
Coarse Aggregate & $\mathrm{kg} / \mathrm{m}^{3}$ & 1293.90 & 1293.90 & 1293.90 & 1293.90 & 1293.90 \\
Waste Carbon Black (WCB) & $\mathrm{kg} / \mathrm{m}^{3}$ & 0 & 85.88 & 173.66 & 259.54 & 345.42 \\
\hline
\end{tabular}

Firstly, the fine and coarse aggregates and cement were mixed for $2 \mathrm{~min}$. After the waste carbon black was added, it was mixed again for $2 \mathrm{~min}$. Then, the required water was added. We mixed until a homogenous and uniform lightweight concrete was formed. For every mix proportion, a fresh concrete test was performed to determine the consistency of concrete according to ASTM C-143 [70]. After successful preparation of a homogenous concrete, the molding of the standard specimen (i.e., $500 \mathrm{~mm}$ $\times 100 \mathrm{~mm} \times 100 \mathrm{~mm}$ ) was carried out and after $24 \mathrm{~h}$ the specimen was demolded and put into a water 
tank for curing purposes according to ASTM C-192 [71]. For each mix ID, three specimens were cast for 7 days and, relatively, for 28 days. For this purpose, a compaction vibrating table was used.

\subsection{Testing Methods}

After demolding, the specimens were dried at room temperature at $23 \pm 2{ }^{\circ} \mathrm{C}$ and then both destructive and non-destructive tests were applied to investigate the behavior of waste carbon black lightweight concrete.

\subsubsection{Non-Destructive Testing}

In this testing, an ultrasonic pulse velocity test was conducted on a standard specimen to determine the carbon black concrete characteristic and uniformity [72,73]. For this aim, the MATEST (Italy) brand apparatus of ultrasonic pulse velocity was employed. The equipment consists of two probes with a frequency of $55 \mathrm{kHz}$, a measuring range of $0-3000 \mu \mathrm{s} \pm 0.1 \mu \mathrm{s}$, and the coupling agent for a firm connection and better transmission. The test was conducted according to ASTM C-597 [74] and the operational diagram is shown in Figure 2.

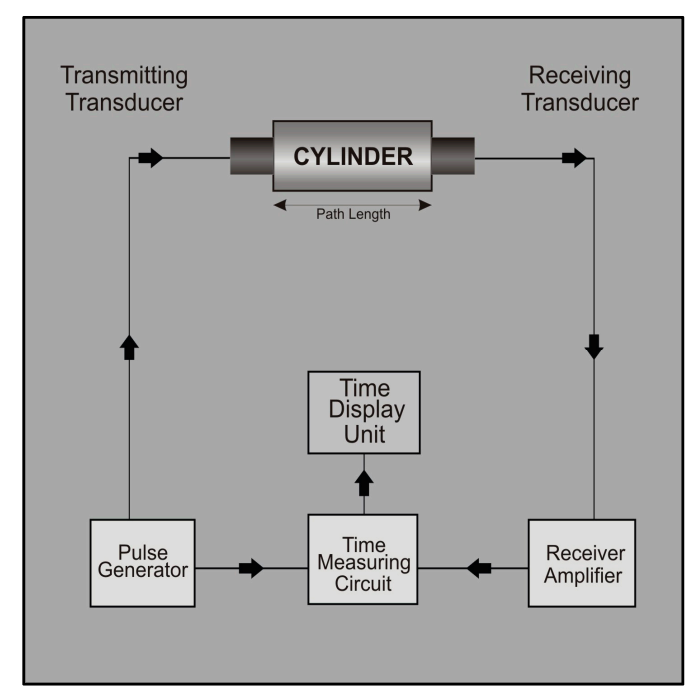

Figure 2. Schematic diagram of ultrasonic pulse velocity.

Firstly, non-destructive testing was applied to every specimen before destructive testing. Then, the waves were passed through each standard specimen. Afterwards, the travel time was noted. Then, with the help of the following equation listed in ASTM C-597 (1) and (2), the velocity $(V)$ and dynamic modulus of elasticity $\left(E_{d}\right)$ were determined and the Poisson's ratio for lightweight concretes was taken $(0.28)[17,75]$.

$$
V=\frac{L}{T}
$$

where

$L=$ travel path length $(\mathrm{m}), T=$ transit $(\mu \mathrm{s}), V=$ pulse velocity $(\mathrm{km} / \mathrm{s})$.

$$
V=\sqrt{\frac{E_{d}(1-\mu)}{\rho(1+\mu)(1-2 \mu)}} .
$$

$\mu=$ Poisson ratio;

$V=$ pulse velocity $(\mathrm{m} / \mathrm{s})$;

$\rho=$ density of concrete $\left(\mathrm{kg} / \mathrm{m}^{3}\right)$;

$E_{d}=$ dynamic modulus of elasticity (GPa). 


\subsubsection{Destructive Testing}

In destructive testing, a compressive and flexural strength test was carried out on specimens to determine their behavior under specific loading. The technique that we applied for the destructive testing on specimens is given below:

Step 1: The third point load flexural strength test was applied on standard prisms (i.e., $500 \mathrm{~mm} \times$ $100 \mathrm{~mm} \times 100 \mathrm{~mm}$ ) according to ASTM C-78 [76], as shown in Figure 3a.

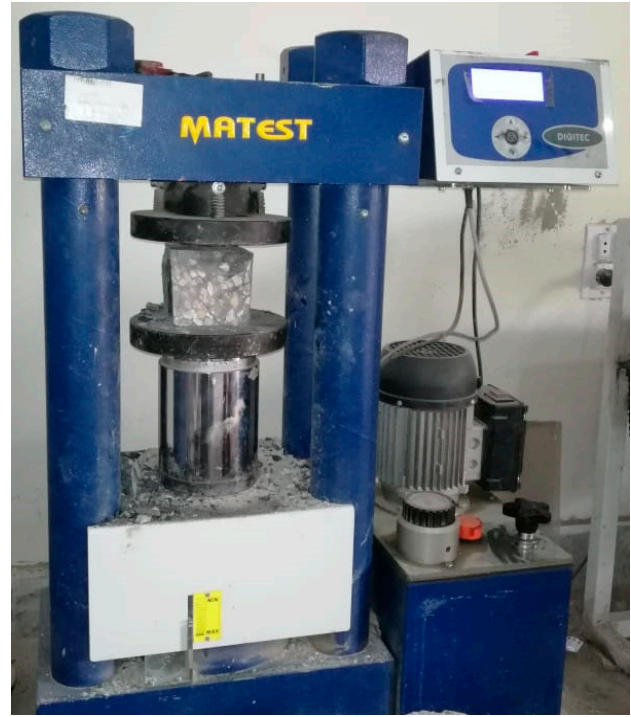

(d)

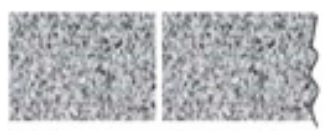

$\overleftarrow{100 \mathrm{~mm}}$

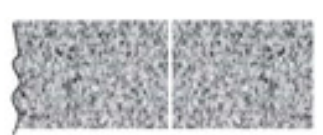

$100 \mathrm{~mm}$
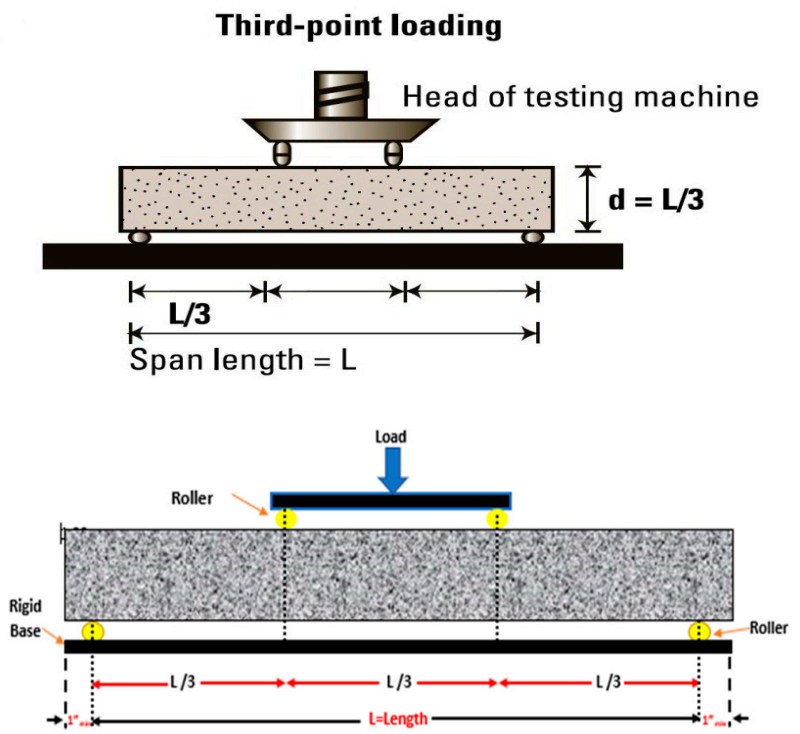

(a)

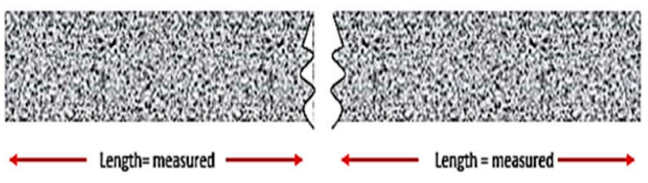

(b)

Figure 3. (a) Flexural strength test mechanism, (b) broken beam diagram after test, (c) cutting section of cubes from the same beam pieces, (d) compression strength test for cube pieces of $100 \mathrm{~mm} \times 100 \mathrm{~mm}$.

Step 2: After the flexural strength test, the prism was broken into two pieces and the length of each piece was evaluated with measuring tape, as shown in Figure $3 \mathrm{~b}$.

Step 3: After measuring each piece, two pieces of $100 \mathrm{~mm} \times 100 \mathrm{~mm} \times 100 \mathrm{~mm}$ cubes were produced by cutting. The mechanism is shown in Figure 3c.

Step 4: The completion of compression strength test cutting conducted on standard $100 \mathrm{~mm} \times$ $100 \mathrm{~mm} \times 100 \mathrm{~mm}$ cubes to investigate their strength is shown in Figure 3(a). For this purpose, the MATEST brand device was utilized at a loading rate of $5 \mathrm{KN} / \mathrm{s}$ with a maximum machine capacity of $2000 \mathrm{KN}$ following the ASTM C-39 [77].

For a better understanding of the results, the flexural strength was computed by using Equation (3) listed in ACI 318 [78].

$$
f_{r}=0.7 \sqrt{f_{c}^{\prime}}
$$

$f_{c}{ }^{\prime}=$ compressive strength $(\mathrm{MPa}) ;$

$f_{r}=$ flexural strength (MPa). 


\section{Results and Discussion}

\subsection{Fresh Concrete Test}

To know about the workability of fresh waste carbon black, a concrete slump test was performed on every replacement of fine aggregates. As the replacement increased, the workability values increased, as shown in Table 5.

Table 5. Workability of Waste Carbon Black (WCB) Lightweight Concrete.

\begin{tabular}{cc}
\hline Mix ID & Slump (cm) \\
\hline WCB-0 & 5.08 \\
WCB-25 & 13.97 \\
WCB-50 & 15.24 \\
WCB-75 & 16.51 \\
WCB-100 & 7.62 \\
\hline
\end{tabular}

It is clearly shown in Table 5 that with the increase in replacement, the workability has increased which results in the decrease of workmanship during the casting of concrete structures. At $100 \%$ of carbon black, the workability was also very good, which indicates that the carbon black has not absorbed a lot of water. Therefore, with a lower water/cement ratio, a good workable concrete can be made by utilizing waste carbon black as a filler material.

\subsection{Density}

When the percentage replacement of carbon black increases, the density of concrete decreases due to the lighter weight of carbon black with respect to fine aggregates. The consequence of carbon black replacement on concrete density and weight reduction is shown in Figure 4.

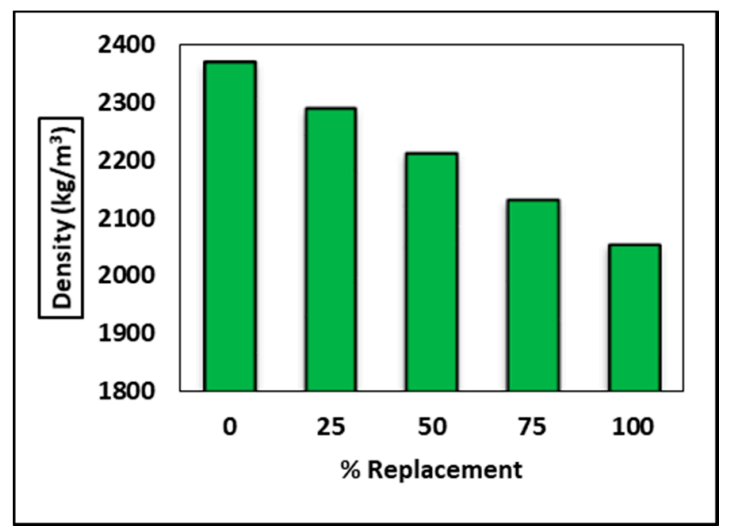

(a)

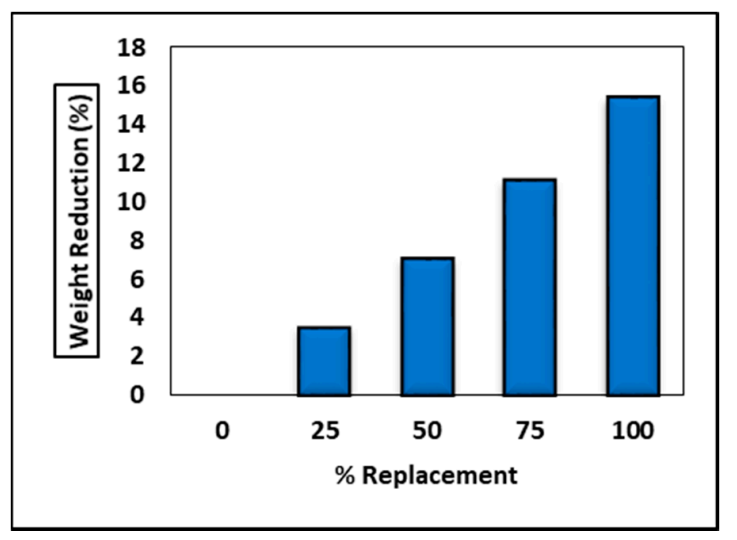

(b)

Figure 4. \% replacement of carbon black. (a) Effect on density, (b) effect on weight reduction.

As shown in the above Figure 4, as the content of carbon black varies, the weight reduction of concrete is increased up to approximately $16 \%$, and the weight is reduced at $100 \%$ replacement. Meanwhile, at $100 \%$ replacement, the density is $2050 \mathrm{~kg} / \mathrm{m}^{3}$. The density of waste carbon black concrete lies in between $2370 \mathrm{~kg} / \mathrm{m}^{3}-2050 \mathrm{~kg} / \mathrm{m}^{3}$. At every $25 \%$ replacement of sand with carbon black at about $3.5 \%$, weight is reduced relative to conventional concrete weight.

\subsection{Non-Destructive Testing}

In this research, the ultrasonic pulse velocity test was also used to analyze the waste carbon black concrete quality and their uniformity and presence of voids. The brief result analysis of non-destructive testing is shown in Figure 5. 


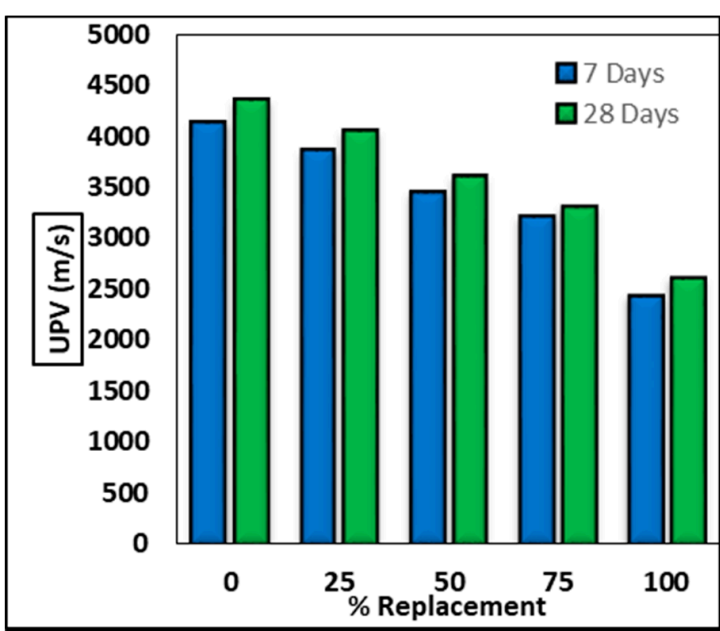

(a)

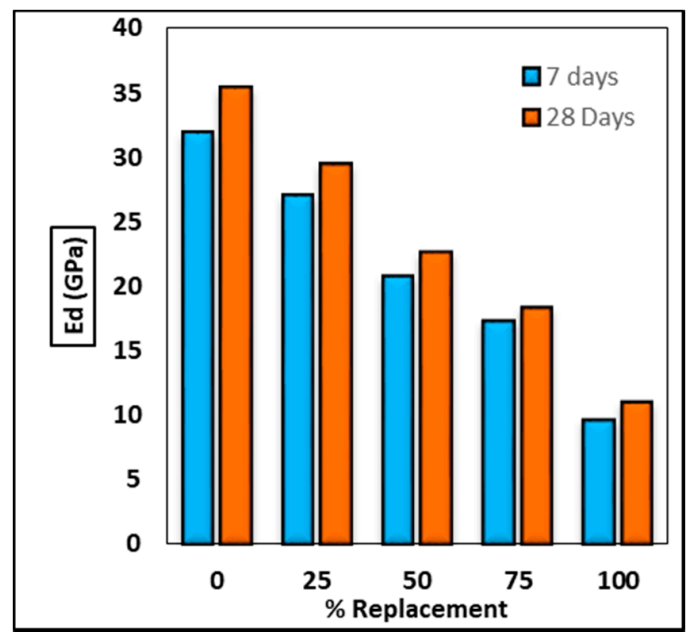

(b)

Figure 5. Non-destructive testing: (a) \% replacement of carbon black effect on UPV and (b) dynamic modulus of elasticity (GPa).

The higher the percentage replacement, the lower the value of velocity. At $0 \%$ replacement, the value of velocity was $4370 \mathrm{~m} / \mathrm{s}$ at 28-days curing, and the value of Ed was about $36 \mathrm{GPa}$. On the other hand, at $100 \%$ replacement, the value of velocity was about $2600 \mathrm{~m} / \mathrm{s}$ and Ed was $11 \mathrm{GPa}$. The value of the velocity at 28-days curing varied from $4370 \mathrm{~m} / \mathrm{s}-2600 \mathrm{~m} / \mathrm{s}$. Meanwhile, the value of the velocity at 7 -days curing varied from $4150 \mathrm{~m} / \mathrm{s}-2448 \mathrm{~m} / \mathrm{s}$. Furthermore, the Ed value varies from $32 \mathrm{GPa}-9 \mathrm{GPa}$ at 7-days curing. For 7- and 28-days curing, the difference between the velocity values at $0 \%$ replacement was about $5.25 \%$.

\subsection{Destructive Testing}

The destructive testing results were very helpful to analyze the true behavior of specimens under specific loading. In this research, compression and flexural strength tests were applied to the standard specimen according to the technique discussed above. The destructive testing results at 7- and 28-days curing are shown in Figure 6.

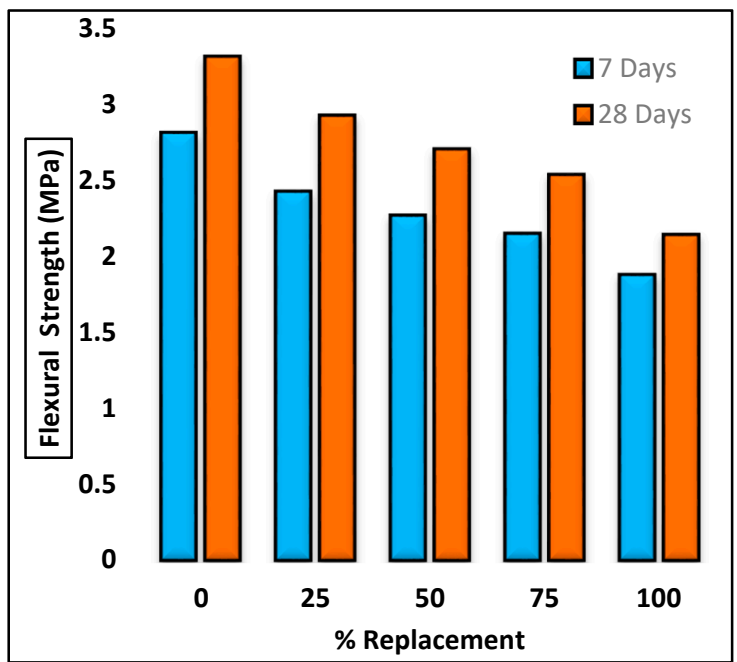

(a)

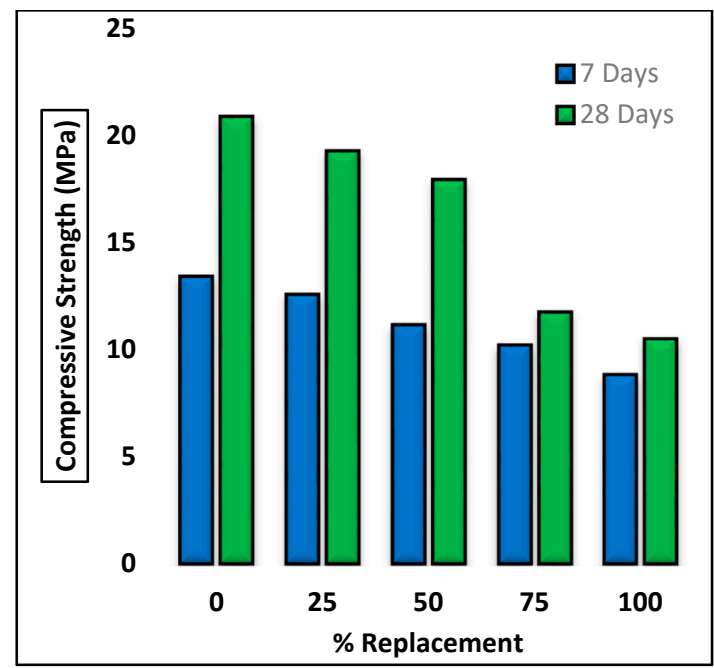

(b)

Figure 6. Destructive testing: (a) compressive strength at 7-days and 28-days curing, (b) flexural strength at 7-days and 28-days curing. 
At $0 \%$ replacement, the value of compressive strength was approximately $13.40 \mathrm{MPa}$ and the flexural strength was about $3 \mathrm{MPa}$. The graphical analysis shows that percentage replacement and destructive testing results are inversely proportional to each other. As the curing period increased, the results of destructive testings showed more efficient results of waste carbon black lightweight concrete. At 28-days curing, the compressive strength at $0 \%$ was approximately $21 \mathrm{MPa}$ and the flexural strength was 3.5 MPa. The percentage difference at 7 - and 28 -days was only $40 \%$ for $0 \%$ replacement. As the percentage replacement increased, the value of destructive testing decreased. At 28-days curing, the strength was not much increased at $75 \%$ and $100 \%$ replacement compared to the 7 -days curing results. It indicates that approximately $85 \%$ of strength at $75 \%$ and $100 \%$ replacement was achieved at 7 -days curing. The comparison between experimental flexural strength and by using Equation (3) is shown in Table 6.

Table 6. Comparison between flexural strength- $\mathbf{f}_{\mathbf{r}}(\mathrm{MPa})$.

\begin{tabular}{cccc}
\hline Mix ID & Experimental $\mathbf{f}_{\mathbf{r}} \mathbf{( M P a )}$ & ACI $\mathbf{f}_{\mathbf{r}}(\mathbf{M P a})$ & \% Difference \\
\hline WCB-0 & 3.31 & 3.20 & -3.43 \\
WCB-25 & 2.93 & 3.07 & +4.78 \\
WCB-50 & 2.71 & 2.96 & +9.23 \\
WCB-75 & 2.54 & 2.40 & -5.51 \\
WCB-100 & 2.15 & 2.27 & +5.58 \\
\hline
\end{tabular}

The experimental values are very close to the value computed through the ACI equation. The highest $\%$ difference is +9.23 for WCB-50.

\subsection{Destructive and Non-Destructive Results}

Non-destructive testing (NDT) results are very helpful to investigate the performance of destructive testing (DT) results. NDT properties are observed with the help of ultrasonic pulse velocity and dynamic modulus of elasticity values. However, DT properties are collected by destructive machine-based testing equipments, such as compressive strength testing machines. Figures 7 and 8 show the comparative results of 28-days destructive and non-destructive testing.

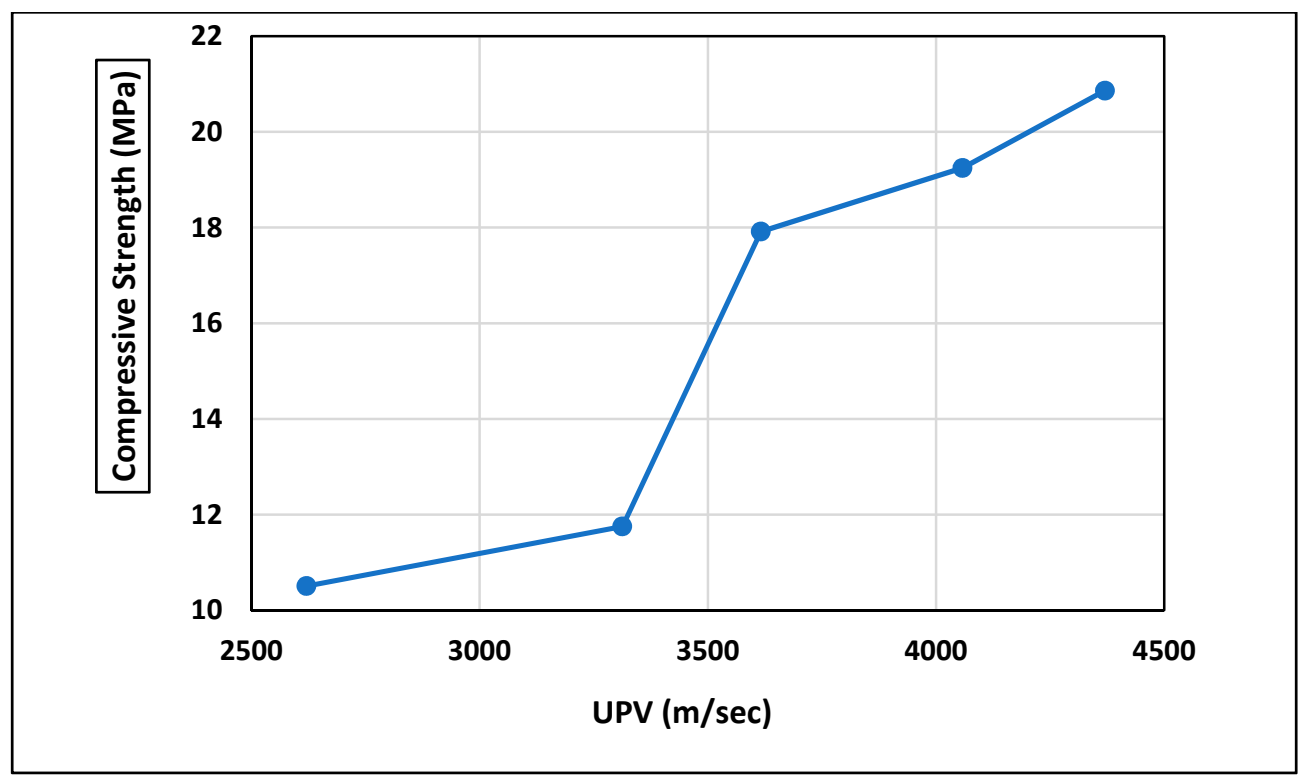

(a)

Figure 7. Cont. 


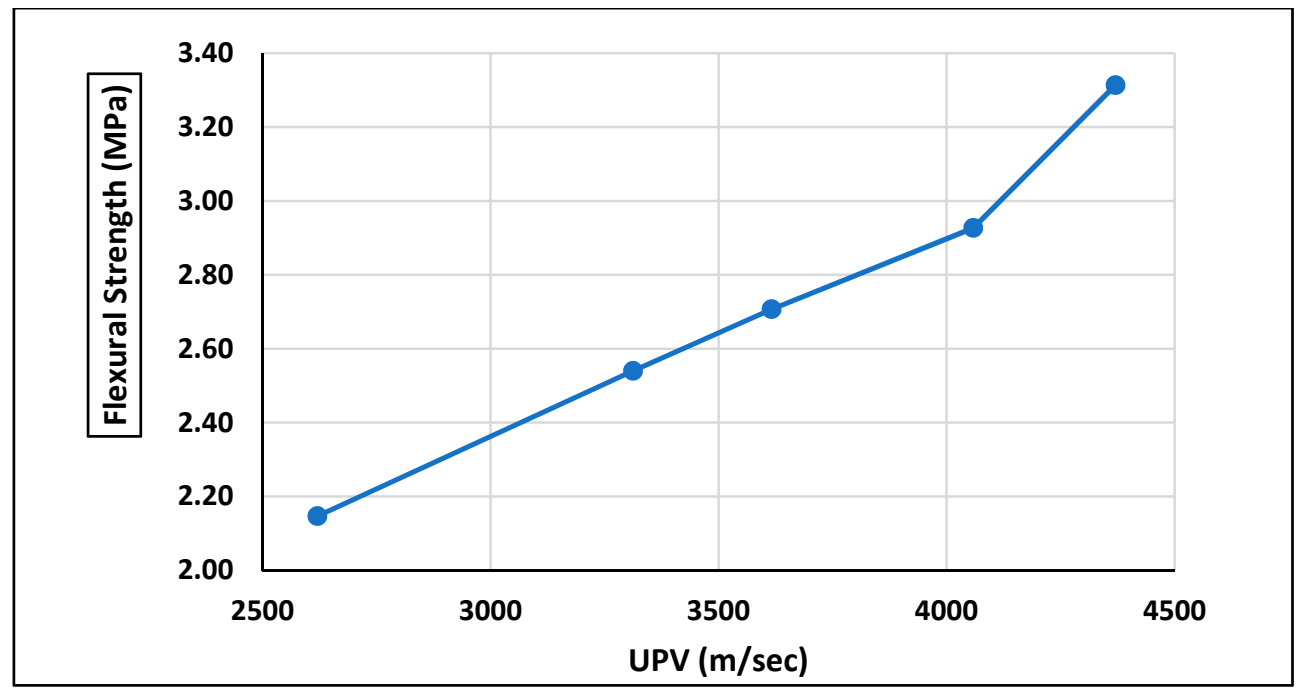

(b)

Figure 7. Non-destructive testing (NDT)-destructive testing (DT): ultrasonic pulse velocity (UPV) vs. (a) compressive strength and (b) flexural strength.

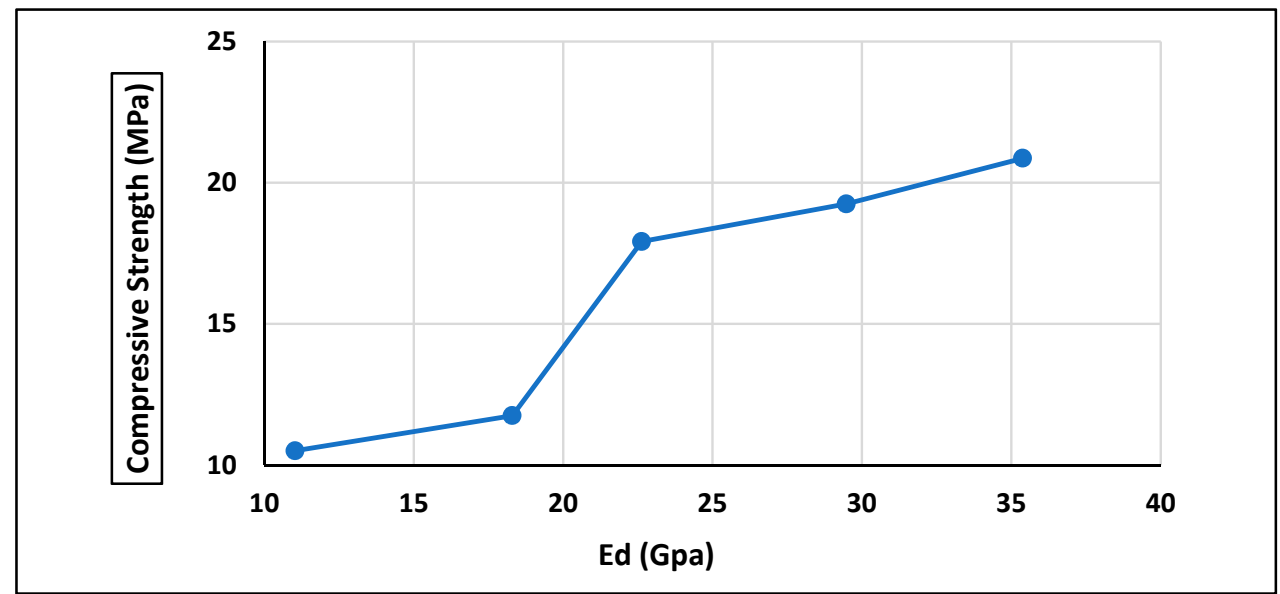

(a)

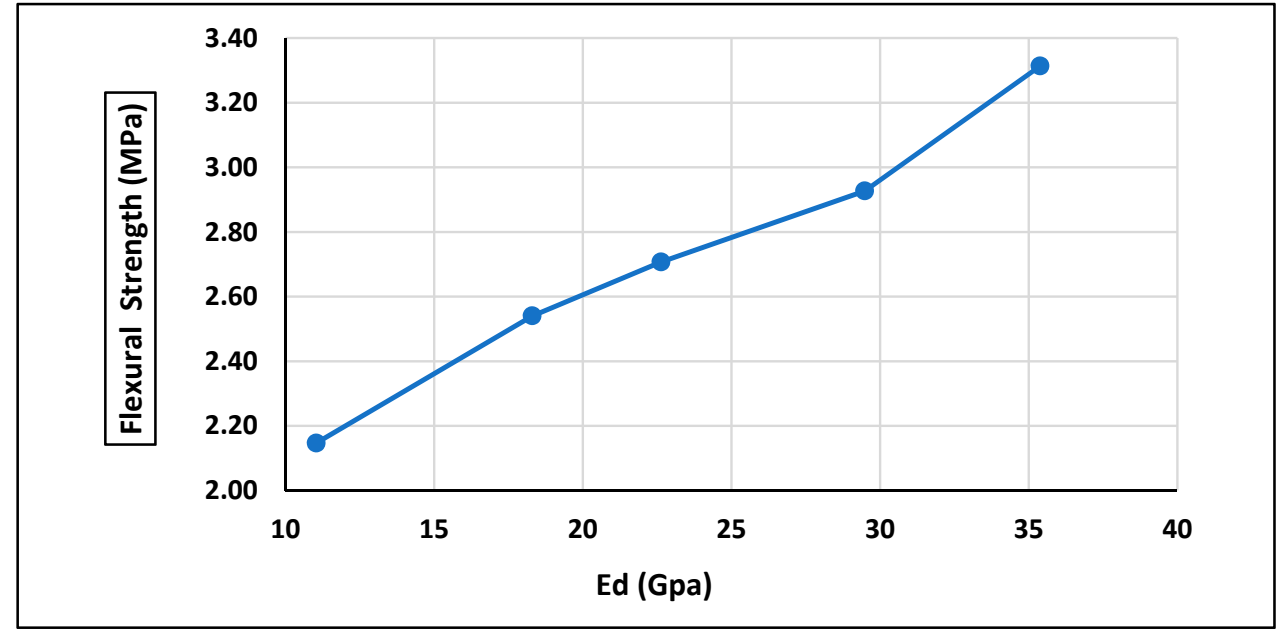

(b)

Figure 8. NDT-DT: dynamic modulus of elasticity (Ed) vs. (a) compressive strength and (b) flexural strength. 
Figures 7 and 8 clearly show the relationship between destructive and non-destructive testing results. As the values of velocity increased, the same the values of destructive testing also improved, which indicates a direct relationship among these testing techniques. Moreover, the amount of the dynamic modulus of elasticity varies. Higher velocity values indicate the uniformity and homogeneity of standard specimens. Because fewer voids were present, the values of compressive and flexural strength were high. Meanwhile, the highest value of compressive strength shows the high value of ultrasonic pulse velocity and dynamic modulus of elasticity. Flexural strength also varies simultaneously to compressive strength.

\subsection{Statistical Analysis}

The statistical analysis is very helpful to analyze the variation of testing values that were obtained during the entire testing. For this purpose, the standard deviation and regression analysis was used to investigate the trending of results. The standard deviation for various parameters at 28-days curing is listed in Table 7. Figure 9 showing the statistical analysis of compressive strength, flexural strength, and ultrasonic pulse velocity at 28-days curing.

Table 7. The standard deviation of destructive and non-destructive testing.

\begin{tabular}{cccc}
\hline Mix ID & UPV (m/s) & Flexural Strength (MPa) & Compressive Strength (MPa) \\
\hline WCB-0 & $4370.44 \pm 11.41$ & $3.31 \pm 0.07$ & $20.86 \pm 1.43$ \\
WCB-25 & $4058.46 \pm 9.96$ & $2.93 \pm 0.07$ & $19.25 \pm 1.15$ \\
WCB-50 & $3616.25 \pm 16.78$ & $2.71 \pm 0.06$ & $17.92 \pm 2.56$ \\
WCB-75 & $3312.80 \pm 20.21$ & $2.54 \pm 0.06$ & $11.75 \pm 1.34$ \\
WCB-100 & $2620.66 \pm 21.08$ & $2.15 \pm 0.07$ & $10.51 \pm 1.41$ \\
\hline
\end{tabular}

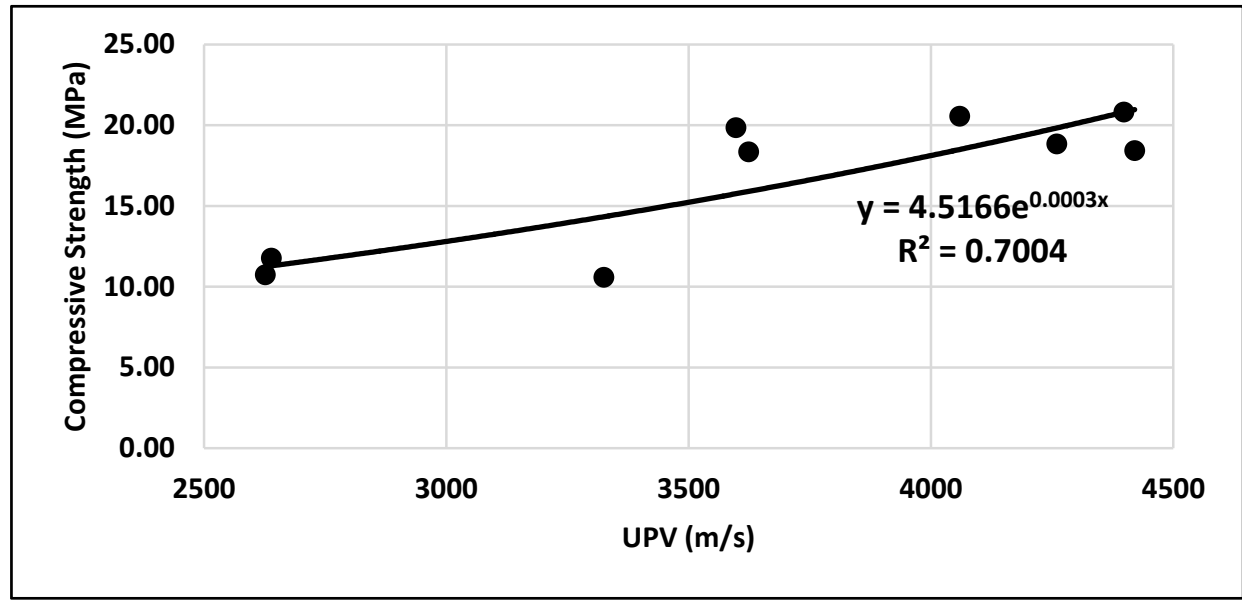

Figure 9. The statistical relationship between compressive strength and ultrasonic pulse velocity.

Figure 9 indicates that the R-Square is 0.70 , which demonstrates a satisfactory relationship between ultrasonic pulse velocity and compressive strength at 28-days curing. Furthermore, an exponential equation is proposed for future research. In Figure 10, the regression analysis is shown, indicating a R-Square of 0.9455 , which demonstrates a very good relationship between ultrasonic pulse velocity and \% replacement at 28 -days curing. 


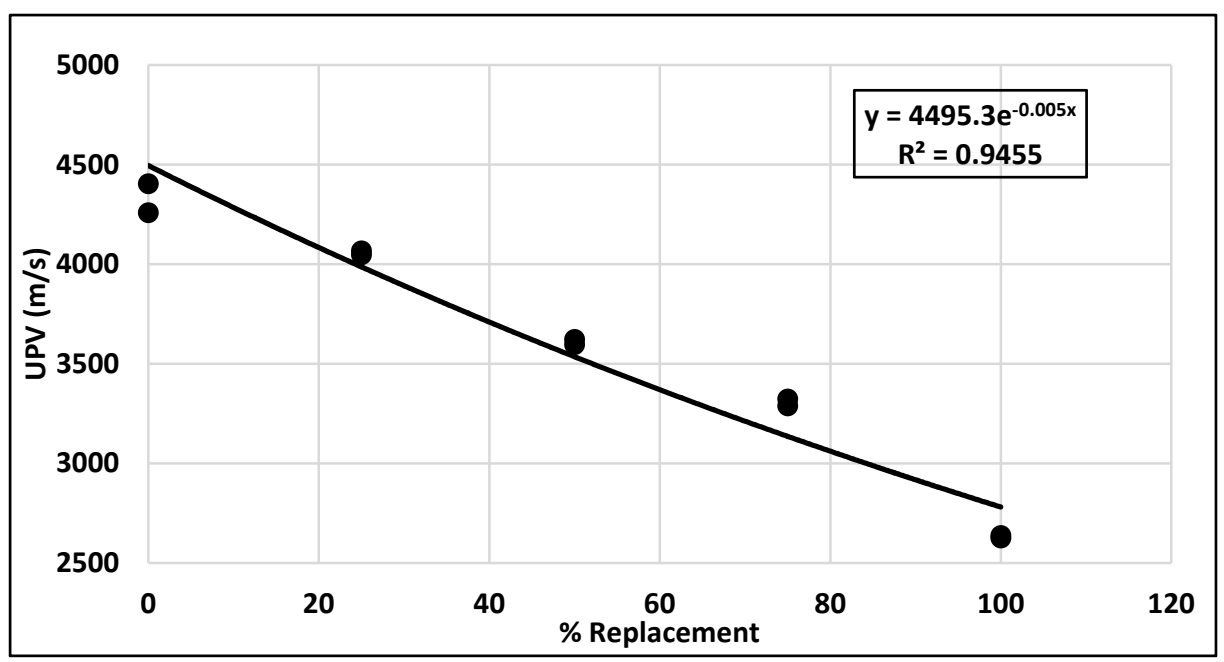

Figure 10. The statistical relationship between \% replacement of carbon black and ultrasonic pulse velocity.

\subsection{Cost Analysis}

After the statistical and graphical investigation of waste carbon black lightweight concrete results, the impact of sand replacement with waste carbon black in terms of cost are also shown in Table 8.

Table 8. Cost analysis for $1 \mathrm{~m}^{3}$ concrete produced using waste carbon black.

\begin{tabular}{ccccccc}
\hline Mix ID & Cement & Aggregate & Sand & WCB & Total & Cost Saving \\
\hline & USD $(\$)$ & USD $(\$)$ & USD $(\$)$ & USD $(\$)$ & USD $(\$)$ & $(\%)$ \\
WCB-0 & 29.39 & 9.81 & 3.93 & 0 & 48.34 & - \\
WCB-25 & 29.39 & 9.81 & 2.94 & 0.48 & 47.83 & 1.06 \\
WCB-50 & 29.39 & 9.81 & 1.96 & 0.98 & 47.35 & 2.05 \\
WCB-75 & 29.39 & 9.81 & 0.98 & 1.46 & 46.85 & 3.08 \\
WCB-100 & 29.39 & 9.81 & 0 & 1.95 & 46.36 & 4.10 \\
\hline
\end{tabular}

Table 8 shows that as the percentage replacement increases, the cost decreases because at $100 \%$ replacement of sand, the fine aggregate cost is approximately zero. This is economically very beneficial for the construction industry in order to save a lot of money against the utilization of waste carbon black.

\section{Conclusions}

This study focused on the utilization of waste carbon black as filler material for the development of concrete. Moreover, the development of lightweight concrete through the utilization of waste carbon black was very effective. Approximately $16 \%$ weight was reduced through the replacement of sand with waste carbon black and, simultaneously, a lot of dead load saving occurred due to the utilization of waste carbon black in concrete. A new technique for the investigation of compressive strength was applied with reference to the equivalent cube test mechanism. The results obtained through this technique were excellent and very helpful for future experimental investigations. Destructive and non-destructive testing, and, later on, statistical analysis were conducted. The performance through the value of the coefficient of determination (R-square) was 0.70 between the ultrasonic pulse velocity and compressive strength results at 28 days of curing condition. Correspondingly, the R-square for $\%$ replacement and ultrasonic pulse velocity was 0.94 . The waste carbon black-based lightweight concrete developed in this study can be utilized for both structural and non-structural purposes. At $25 \%$ and 50\% replacement the strength of lightweight concrete varied from 20-18 MPa and, according to ACI lightweight concrete, if 28 days strength is $\geq 17 \mathrm{MPa}$, it can be used as structural concrete [79]. The remaining $75 \%$ and $100 \%$ replacement concrete can be used for non-structural purposes. This 
study will help in the development of economical eco-friendly sustainable concrete materials and black carbon waste management.

Author Contributions: Conceptualization, F.A. and S.A.R.S.; data curation, F.A., M.A.K., M.A.Q., and Z.K.; formal analysis, M.A.Q., S.A.R.S., and H.A.; investigation, Z.K. and H.S.R.; methodology, S.A.R.S. and H.A.; project administration, S.A.R.S.; resources, F.A., M.A.K., and Z.K.; software, M.A.Q.; supervision, S.A.R.S., N.M.K., H.A., and M.F.; validation, N.M.K. and M.F.; writing-original draft, M.A.Q. and S.A.R.S.; writing-review and editing, N.M.K., H.A., M.F., and M.W. All authors have read and agreed to the published version of the manuscript.

Funding: This research received no external funding.

Conflicts of Interest: The authors declare no conflict of interest.

\section{References}

1. Ismail, I.; Saim, A.A.; Latif Saleh, A. Properties of hardened concrete bricks containing expanded polystyrene beads. In Proceedings of the 5th Asia-Pacific Structural Engineering and Construction Conference, Johor Bahru, Malaysia, 26-28 August 2003.

2. Scrivener, K.L.; Kirkpatrick, R.J. Innovation in use and research on cementitious material. Cem. Concr. Res. 2008, 38, 128-136. [CrossRef]

3. Padma, B.; Pandeeswari, K. Experimental investigation on the properties of concrete with carbon black and PET. Int. J. Adv. Res. 2016, 4, 1082-1088.

4. Manoharan, P.; Ravichandran, P.T.; Annadurai, R.; Rajkumar, P.K. Studies on Properties of Concrete Using Crumb Rubber as Fine Aggregate. In International Conference on Intelligent Computing and Applications; Springer: Singapore, 2019; pp. 197-203.

5. $\mathrm{Xu}, \mathrm{Y} . ;$ Jiang, L.; $\mathrm{Xu}, \mathrm{J}$.; Li, Y. Mechanical properties of expanded polystyrene lightweight aggregate concrete and brick. Constr. Build. Mater. 2012, 27, 32-38. [CrossRef]

6. Babu, D.S.; Babu, K.G.; Tiong-Huan, W. Effect of polystyrene aggregate size on strength and moisture migration characteristics of lightweight concrete. Cem. Concr. Compos. 2006, 28, 520-527. [CrossRef]

7. Alshihri, M.M.; Azmy, A.M.; El-Bisy, M.S. Neural networks for predicting compressive strength of structural light weight concrete. Constr. Build. Mater. 2009, 23, 2214-2219. [CrossRef]

8. Yasar, E.; Atis, C.D.; Kilic, A.; Gulsen, H. Strength properties of lightweight concrete made with basaltic pumice and fly ash. Mater. Lett. 2003, 57, 2267-2270. [CrossRef]

9. Schackow, A.; Effting, C.; Folgueras, M.V.; Güths, S.; Mendes, G.A. Mechanical and thermal properties of lightweight concretes with vermiculite and EPS using air-entraining agent. Constr. Build. Mater. 2014, 57, 190-197. [CrossRef]

10. Chen, B.; Liu, J. Contribution of hybrid fibers on the properties of the high-strength lightweight concrete having good workability. Cem. Concr. Res. 2005, 35, 913-917. [CrossRef]

11. Ferrándiz-Mas, V.; García-Alcocel, E. Durability of expanded polystyrene mortars. Constr. Build. Mater. 2013, 46, 175-182. [CrossRef]

12. Sayadi, A.A.; Tapia, J.V.; Neitzert, T.R.; Clifton, G.C. Effects of expanded polystyrene (EPS) particles on fire resistance, thermal conductivity and compressive strength of foamed concrete. Constr. Build. Mater. 2016, 112, 716-724. [CrossRef]

13. Chia, K.S.; Zhang, M.H. Water permeability and chloride penetrability of high-strength lightweight aggregate concrete. Cem. Concr. Res. 2002, 32, 639-645. [CrossRef]

14. Kitouni, S.; Houari, H. Lightweight concrete with Algerian limestone dust. Part II: Study on $50 \%$ and $100 \%$ replacement to normal aggregate at timely age. Cerâmica 2015, 61, 462-468. [CrossRef]

15. Zhang, X.; Deng, D.; Yang, J. Mechanical Properties and Conversion Relations of Strength Indexes for Stone/Sand-Lightweight Aggregate Concrete. Adv. Mater. Sci. Eng. 2018, 2018, 5402953. [CrossRef]

16. Bogas, J.A.; Gomes, M.G.; Gomes, A. Compressive strength evaluation of structural lightweight concrete by non-destructive ultrasonic pulse velocity method. Ultrasonics 2013, 53, 962-972. [CrossRef]

17. Qurashi, M.A.; Shah, S.A.R.; Farhan, M.; Taufiq, M.; Khalid, W.; Arshad, H.; Waseem, M. Sustainable Design and Engineering: A Relationship Analysis between Digital Destructive and Non-Destructive Testing Process for Lightweight Concrete. Processes 2019, 7, 791. [CrossRef]

18. Sadrmomtazi, A.; Sobhani, J.; Mirgozar, M.A.; Najimi, M. Properties of multi-strength grade EPS concrete containing silica fume and rice husk ash. Constr. Build. Mater. 2012, 35, 211-219. [CrossRef] 
19. Colangelo, F.; Messina, F.; Di Palma, L.; Cioffi, R. Recycling of non-metallic automotive shredder residues and coal fly-ash in cold-bonded aggregates for sustainable concrete. Compos. Part B 2017, 116, 46-52. [CrossRef]

20. Sabaa, B.; Ravindrarajah, R.S. Engineering properties of lightweight concrete containing crushed expanded polystyrene waste. In Proceedings of the Symposium MM: Advances in Materials for Cementitious Composites, Boston, MA, USA, 1-3 December 1997.

21. Colangelo, F.; Cioffi, R.; Liguori, B.; Iucolano, F. Recycled polyolefins waste as aggregates for lightweight concrete. Compos. Part B 2016, 106, 234-241. [CrossRef]

22. Václavík, V.; Dvorský, T.; Dirner, V.; Daxner, J.; Št'astný, M. Polyurethane foam as aggregate for thermal insulating mortars and lightweight concrete. Tech. Gazette 2012, 19, 665-672.

23. Thomas, B.S.; Gupta, R.C. A comprehensive review on the applications of waste tire rubber in cement concrete. Renew. Sustain. Energy Rev. 2016, 54, 1323-1333. [CrossRef]

24. Thomas, B.S.; Gupta, R.C.; Panicker, V.J. Recycling of waste tire rubber as aggregate in concrete: Durability-related performance. J. Clean. Prod. 2016, 112, 504-513. [CrossRef]

25. Williams, P.T.; Besler, S.; Taylor, D.T. The pyrolysis of scrap automotive tyres: The influence of temperature and heating rate on product composition. Fuel 1990, 69, 1474-1482. [CrossRef]

26. Garrick, G.M. Analysis and Testing of Waste Tire Fiber Modified Concrete. LSU Master's Thesis, Louisiana State University and Agricultural and Mechanical College, Baton Rouge, LA, USA, 2005.

27. Hernández-Olivares, F.; Barluenga, G.; Parga-Landa, B.; Bollati, M.; Witoszek, B. Fatigue behaviour of recycled tyre rubber-filled concrete and its implications in the design of rigid pavements. Constr. Build. Mater. 2007, 21, 1918-1927. [CrossRef]

28. Khatib, Z.K.; Bayomy, F.M. Rubberized Portland cement concrete. J. Mater. Civ. Eng. 1999, 11, $206-213$. [CrossRef]

29. Atahan, A.O.; Yücel, A.Ö. Crumb rubber in concrete: Static and dynamic evaluation. Constr. Build. Mater. 2012, 36, 617-622. [CrossRef]

30. Najim, K.B.; Hall, M.R. Mechanical and dynamic properties of self-compacting crumb rubber modified concrete. Constr. Build. Mater. 2012, 27, 521-530. [CrossRef]

31. Al-Tayeb, M.M.; Bakar, B.A.; Ismail, H.; Akil, H.M. Effect of partial replacement of sand by recycled fine crumb rubber on the performance of hybrid rubberized-normal concrete under impact load: Experiment and simulation. J. Clean. Prod. 2013, 59, 284-289. [CrossRef]

32. Bravo, M.; De Brito, J. Concrete made with used tyre aggregate: Durability-related performance. J. Clean. Prod. 2012, 25, 42-50. [CrossRef]

33. Youssf, O.; ElGawady, M.A.; Mills, J.E.; Ma, X. An experimental investigation of crumb rubber concrete confined by fibre reinforced polymer tubes. Constr. Build. Mater. 2014, 53, 522-532. [CrossRef]

34. Ganjian, E.; Khorami, M.; Maghsoudi, A.A. Scrap-tyre-rubber replacement for aggregate and filler in concrete. Constr. Build. Mater. 2009, 23, 1828-1836. [CrossRef]

35. Turatsinze, A.; Bonnet, S.; Granju, J.L. Potential of rubber aggregates to modify properties of cement based-mortars: Improvement in cracking shrinkage resistance. Constr. Build. Mater. 2007, 21, 176-181. [CrossRef]

36. Ho, A.; Turatsinze, A.; Vu, D. On the potential of rubber aggregates obtained by grinding end-of-life tyres to improve the strain capacity of concrete. In Concrete Repair, Rehabilitation and Retrofitting II; CRC Press/Balkema: AK Leiden, The Netherlands, 2008.

37. Martínez, J.D.; Cardona-Uribe, N.; Murillo, R.; García, T.; López, J.M. Carbon black recovery from waste tire pyrolysis by demineralization: Production and application in rubber compounding. Int. J. Environ. Waste Manag. 2019, 85, 574-584. [CrossRef] [PubMed]

38. Zabaniotou, A.; Antoniou, N.; Bruton, G. Analysis of good practices, barriers and drivers for ELTs pyrolysis industrial application. Waste Manag. 2014, 34, 2335-2346. [CrossRef] [PubMed]

39. Raza, M.A.; Vakil, A.; Anjum, N.; Gani, T.; Ansari, A. A Review on Influence of Manufacturing Waste (Carbon Black) on Properties of Concrete. Int. J. Sci. Res. Sci. Technol. (IJSRST). 2018, 4, 129-131.

40. Sagar, M.; Nibedita, K.; Manohar, N.; Kumar, K.R.; Suchismita, S.; Pradnyesh, A.; Jayaramudu, J.A. potential utilization of end-of-life tyres as recycled carbon black in EPDM rubber. Waste Manag. 2018, 74, 110-122. [CrossRef]

41. Gómez-Hernández, R.; Panecatl-Bernal, Y.; Méndez-Rojas, M.Á. High yield and simple one-step production of carbon black nanoparticles from waste tires. Heliyon 2019, 5, e02139. [CrossRef] 
42. Ding, Y.; Chen, Z.; Han, Z.; Zhang, Y.; Pacheco-Torgal, F. Nano-carbon black and carbon fiber as conductive materials for the diagnosing of the damage of concrete beam. Constr. Build. Mater. 2013, 43, 233-241. [CrossRef]

43. Wen, S.; Chung, D.D.L. Partial replacement of carbon fiber by carbon black in multifunctional cement-matrix composites. Carbon 2007, 45, 505-513. [CrossRef]

44. Ding, Y.; Liu, G.; Hussain, A.; Pacheco-Torgal, F.; Zhang, Y. Effect of steel fiber and carbon black on the self-sensing ability of concrete cracks under bending. Constr. Build. Mater. 2019, 207, 630-639. [CrossRef]

45. Jeyashree, T.; Chitra, G. Experimental Studies on Concrete Elements Using waste Carbon Black as Filler Material. Asian J. Civ. Eng. (BHRC) 2017, 18, 21-30.

46. Dehghanpour, H.; Yilmaz, H.K.; Ipek, M. Evaluation of recycled nano carbon black and waste erosion wires in electrically conductive concretes. Constr. Build. Mater. 2019, 221, 109-121. [CrossRef]

47. Xiao, W.; Sun, Q.; Liu, J.; Xiao, B.; Glans, P.A.; Li, J.; Li, R.; Guo, J.; Yang, W.; Sham, T.K.; et al. Utilizing the full capacity of carbon black as anode for Na-ion batteries via solvent co-intercalation. J. Nano Res. 2017, 10, 4378-4387. [CrossRef]

48. Masadeh, $\mathrm{S}$. The effect of added carbon black to concrete mix on corrosion of steel in concrete. Miner. Mater. Charact. Eng. 2015, 3, 271. [CrossRef]

49. Santhiago, M.; Corrêa, C.C.; Bernardes, J.S.; Pereira, M.P.; Oliveira, L.J.; Strauss, M.; Bufon, C.C. Flexible and foldable fully printed carbon black conductive nanostructures on paper for high-performance electronic, electrochemical, and wearable devices. ACS Appl. Mater. Interfaces 2017, 9, 24365-24372. [CrossRef] [PubMed]

50. Goldman, A.; Bentur, A. The influence of microfillers on enhancement of concrete strength. Cem. Concr. Res. 1993, 23, 962-972. [CrossRef]

51. Lim, S.X.; Wong, K.L.; Zhang, Z.; Neto, A.H.C.; Sow, C.H. Polychromic carbon black: Laser galvanized multicolour fluorescence display. J. Nano Res. 2019, 12, 733-740. [CrossRef]

52. Paczosa-Bator, B.; Cabaj, L.; Piech, R.; Skupień, K. Potentiometric sensors with carbon black supporting platinum nanoparticles. Anal. Chem. 2013, 85, 10255-10261. [CrossRef]

53. Kharita, M.; Yousef, S.; AlNassar, M. The effect of carbon powder addition on the properties of hematite radiation shielding concrete. Prog. Nucl. Energy 2009, 51, 388-392. [CrossRef]

54. Chitra, G.; Selvi, P.V.; Vijayalakshmi, D. Carbon black as an additive in conventional concrete. Int. J. Emerg. Tech. Adv. Eng. 2014, 4, 194-201.

55. Srivastava, S.K.; Mishra, Y.K. Nanocarbon reinforced rubber nanocomposites: Detailed insights about mechanical, dynamical mechanical properties, payne, and mullin effects. Nanomaterials 2018, 8, 945. [CrossRef]

56. Carbas, R.J.; da Silva, L.F.; Andrés, L.F. The Mechanical Response of a Structural Epoxy Adhesive Reinforced with Carbon Black Nanoparticles. Microsc. Microanal. 2019, 25, 187-191. [CrossRef] [PubMed]

57. ASTM C150-07. Standard Specification for Portland Cement; American Society for Testing and Materials: West Conshohocken, PA, USA, 2007.

58. ASTM C114-06. Standard Test Methods for Chemical Analysis of Hydraulic Cement; American Society for Testing of Materials: Philadelphia, PA, USA, 2004.

59. ASTM C187-98. Standard Test Method for Normal Consistency of Hydraulic Cement; Annual Book of ASTM Standards, American Society for Testing and Material: West Conshohocken, PA, USA, 2002.

60. ASTM C191-13. Standard Test Methods for Time of Setting of Hydraulic Cement by Vicat Needle; ASTM International: West Conshohocken, PA, USA, 2013.

61. ASTM C188-17. Standard Test Method for Density of Hydraulic Cement; American Society for Testing and Material: West Conshohocken, PA, USA, 2009.

62. BSI, BS EN 196-3. Methods of Testing Cement-Part 3: Determination of Setting Times and Soundness; British Standards Institution: London, UK, 2005.

63. ASTM C136-01. Standard Test Method for Sieve Analysis of Fine and Coarse Aggregates; Annual Book of Standards, American Society for Testing and Material: West Conshohocken, PA, USA, 2002.

64. ASTM C33/C33M-11a. Standard Specification for Concrete Aggregates; American Society for Testing and Material: West Conshohocken, PA, USA, 2004; pp. 1-11.

65. ASTM C29/C29M-07. Standard Test Method for Bulk Density (Unit Weight) and Voids in Aggregate; ASTM International: West Conshohocken, PA, USA, 2007. 
66. BSI B812-112:1990. Testing Aggregates. Method for Determination of Aggregate Impact Value (AIV); British Standards Institution: London, UK, 1990.

67. BSI B812-110:1990. Testing Aggregates-Methods for Determination of Aggregate Crushing Value (ACV); British Standards Institution: London, UK, 1990.

68. ASTM C131/C131M. Standard Test Method for Resistance to Degradation of Small-Size Coarse Aggregate by Abrasion and Impact in the Los Angeles Machine; ASTM: West Conshohocken, PA, USA, 2008.

69. ASTM C128-15. Standard Test Method for Relative Density (Specific Gravity) and Absorption of Coarse Aggregate; ASTM: West Conshohocken, PA, USA, 2015.

70. ASTM C143/C143M-05a. Standard Test Method for Slump of Hydraulic-Cement Concrete; ASTM: Philadelphia, PA, USA, 2005.

71. ASTM C192/C192M-18. Standard Practice for Making and Curing Concrete Test Specimens in the Laboratory; ASTM International: West Conshohocken, PA, USA, 2018.

72. Shetty, M.S. Concrete Technology, 2nd ed.; S. Chand \& Company Ltd.: New Delhi, India, 2005.

73. Malhotra, V.M.; Carino, N.J. Handbook on Nondestructive Testing of Concrete; CRC Press: West Conshohocken, PA, USA, 2004.

74. ASTM C597-16. Standard Test Method for Pulse Velocity through Concrete; ASTM International: West Conshohocken, PA, USA, 2009.

75. Al-Amawee, A.H.; Salman, M.M. The Ratio between Static and Dynamic Modulus of Elasticity in Normal and High Strength Concrete. J. Eng. Sustain. Dev. 2006, 10, 163-174.

76. ASTM C78/C78M-18. Standard Test Method for Flexural Strength of Concrete (Using Simple Beam with Third-Point Loading); American Society for Testing and Materials: Conshohocken, PA, USA, 2010.

77. ASTM C39/C39M-18. Standard Test Method for Compressive Strength of Cylindrical Concrete Specimens; Annual book of ASTM standards: Conshohocken, PA, USA, 2018.

78. McCormac, J.C.; Brown, R.H. Design of Reinforced Concrete; John Wiley \& Sons: Manhattan, NY, USA, 2015.

79. Akers, D.J.; Gruber, R.D.; Ramme, B.W.; Boyle, M.J.; Grygar, J.G.; Rowe, S.K.; Bremner, T.W.; Kluckowski, E.S.; Sheetz, S.R.; Burg, R.G.; et al. Guide for Structural Lightweight-Aggregate Concrete; ACI 213R-03; American Concrete Institute (ACI): Michigan, MI, USA, 2003.

(C) 2020 by the authors. Licensee MDPI, Basel, Switzerland. This article is an open access article distributed under the terms and conditions of the Creative Commons Attribution (CC BY) license (http://creativecommons.org/licenses/by/4.0/). 